\title{
Syntactical Errors in Students' Writing: A case study of multilingual classrooms in India
}

\author{
Devi Hellystia \\ Gunadarma University, Indonesia \\ E-mail: devi_hellystia@staff.gunadarma.ac.id
}

\begin{abstract}
English is widely used as a tool for academic interaction in multilingual countries like India, however teaching English becomes very challenging particularly writing. Teachers have to face a heterogeneous group of students with a multilingual and multicultural background and they tend to bring their local languages and cultures which may affect their ability in English writing. There is an indication that the students insert patterns in their mother tongues when they are involved in writing activities. This paper deals with the syntactical errors found among multilingual learners from an Engineering college in Bhubaneswar, India. The tests were conducted for the undergraduate students who belonged to the 2 nd and 4th semester. Written tests were conducted for 130 students in the form of passage and a written essay. The research finding showed that misordering is the highest error rate committed by students with a total percentage of $48 \%$. It is followed by other findings they are, $24 \%$ of misformation, $8,2 \%$ of omission, and $20 \%$ of addition.
\end{abstract}

Keywords: syntactical error, multilingual classrooms, multicultural

\section{INTRODUCTION}

Writing is a crucial component of language performances. English writing in both educational and professional settings is increasingly important in countries of non-native speakers of English (Leki, 2001:199). Most of Science and Technology students are required to write various genres of writing summaries, internship report, and research proposal. ESL learners often find that writing is a difficult task. One reason is that good writing requires text with the complexity of syntax and morphology, a wide range of vocabulary, and a good command over conventional forms and over the means of signaling the relation of the texts (Cumming, 2001:3). The ability to write effectively is crucial in second language acquisition. Abusaeedi and Ashgar (2015) claimed that writing is dynamic, nonlinear and involves multiple processes, therefore it is clear that not everyone can become a writer especially in L2. With all these details, the second language students, particularly in the context of the multilingual classroom like India, find English writing becomes a challenging assignment.

Writing is a difficult process which demands cognitive analysis and linguistic synthesis. It is twice harder to learn to write in a foreign language, and it takes time and effort to become skillful in writing (Seitova, 2016). Due to the difficulty the L2, writers encounter when they carry the burden of acquiring English and learning to write simultaneously (Hyland, 2003), students often commit errors occurring as an inevitable part of EFL student writing. Amin (2017) indicates that the interference of the native language occurs when EFL writers apply the linguistic elements, structures or rules of their native language in the production of the target language. In other words, native language interference is derived from the learners' use of 
previously learned knowledge to succeed in learning a new language (Littlewood, 2002). As a result, errors from using incorrect rules of the target language are manifested.

Many studies pertaining to syntactical errors have been carried out, some of them are Jayasundara and Premarathna (2011) who make the identification of errors made by students from Uva Wellassa University in the central part of Sri Lanka. Their study focused on both speaking and writing and they classified the errors into broad categories as Grammar, Syntactic, Semantic, Lexical, Orthography, Morphology and Phonology. These categories seem overlapping because grammar covers all kinds of errors such as morphological and syntactic errors, whereas lexical and morphological errors are related (Ballard, 2013). Neither did the researchers define their error categories. Therefore, the results were not taken into the discussion in the present study. Previous action research conducted by Navaz (2016) identified errors as broad categories as wrong tense usage and spelling errors and the study was undertaken as an intervention study on improving students' writing skills at the same faculty where the present study was conducted. To the knowledge of the researcher, any systematic study on errors especially identifying inflectional errors was not carried out in Sri Lanka. Hence, observing the occurrence of abundant errors made by the students in the South Eastern University, mainly the errors in forming irregular inflectional morphemes, the present study was undertaken to systematically look into the learner errors and to find whether an intervention would improve the situation.

It is obvious that the errors in writing resulted from the interference of the native language are an inevitable occurrence which a majority of ESL learners have experienced. Unfortunately, such interference often causes the inaccuracy and the incomprehensible meaning of the written texts. Consequently, errors in writing and the interference of the native language have become a central issue that many researchers in the field of linguistics and language learning have made tremendous efforts in exploring ways to help the ESL learners to overcome writing difficulties. However, the research study of the reasons and the process of the native language interference in writing performances of ESL learners is scarce, causing a lack of insights on the native language interference phenomenon. This study aims at answering the research questions; (1) what type of syntactical errors are committed by the learners?, (2) what are the causes for syntactical errors in learners' writing?

\section{Errors versus mistakes}

Alkhesheh (2016) argues there are certain ways to distinguish between an error and a mistake. The first one is associated with checking the consistency of the L2 learner's performance. If a learner sometimes uses the correct form of a certain structure or rule and later on uses the wrong one, then it is a mistake and can be self-corrected. However, if he or she always uses it wrongly, then it is an error. The second way is associated with asking an L2 learner to correct his or her deviant utterance. In case he or she is unable to, the deviations are errors, and where he or she is successful, they are definitely mistakes. There are certain ways to distinguish between an error and a mistake. The first one is associated with checking the consistency of the L2 learners' performance. If a learner sometimes uses the correct form of a certain structure or rule and later on uses the wrong one, then it is a mistake and can be self-corrected. However, if he or she always uses it wrongly, then it is an error. The second way is associated with asking an L2 learner to correct his or her deviant utterance. In case that she or he is unable to, the deviations are errors, and where the students are successful, they are definitely mistakes. Before having an in-depth analysis of learners' language in a multilingual classroom 
in an appropriate perspective, it is necessary to distinguish between errors and mistakes. Brown (2000) stated a mistake refers to a failure in using the system which has been known correctly. A mistake is not a result of lack incompetence but the result of some sort of temporary breakdown or imperfection in the process of producing speech and it can be selfcorrected, while an error is a noticeable deviation from the learner language which reflects the competence of the learner. An error cannot be self-corrected.

\section{Errors in language learning}

Like all types of human learning, language learning involves errors committed by the students. The current conception of the foreign language learning is that the learners conduct hypotheses about the systematic rules in of the target language, test those hypotheses against the perceived information, and make adjustment accordingly (Hadley, 2001:101). As a consequent, an error is perceived as the evidence resulting from the language learning process in which the learners use various strategies in learning a new language as well as test the hypotheses, thus errors in language learning occur systematically and repeatedly without any notice by the learners (Gass \& Selinker, 2008: 102).

The errors are identifiable by teachers or others who possess an accurate knowledge of the grammatical system. It should be considered as an indicator of the teaching process, it has a correcting function and it becomes a starting point of new progress in further learning. Lindemann (as cited in Ondrakova, 2016) offers a method that considers contrastive analysis towards the learning material as the beginning of the research on foreign languages acquisition. Teaching foreign languages supported by a textbook that presents scientific descriptions of the target language and student mother tongue is proven to be the most effective method.
Through systematic contrast analysis of the first language and the foreign language, errors can be anticipated, the teaching process can basically be improved and the quality of study materials can increase. The teacher must first go back to the level of the student to really understand what and how students think. Errors cannot be seen as deviations from the norm, they must be understood as the students' mental processes.

\section{The classification of errors}

Dulay et al. (as cited in Tizazu, 2014) classified errors into 4 types they are; a) Addition which refers to the presence of an element or a form which must not appear in a well-formed utterance. Addition errors are sub-categorized into regularization i.e applying rules used to produce the regular ones to those exceptions to the rules; double-marking, a kind of addition error in which one feature is marked at two levels; simple additions are those which are neither regularizations nor double-markings. b) Omission which is triggered by the absence of an item that must appear in a well-formed utterance. c) Misordering caused by incorrect placement of a morpheme or group of morphemes in a given utterance. d) Misformation refers to the use of a wrong form of a morpheme or a structure in an utterance. Ellis indicates (as cited in Gayo \& Widodo, 2018) omission of particular language items may not appear in good utterances, additions indicate the addition of certain linguistics items, misinformation indicates the use of certain linguistic forms that are improper in the target language, and disturbances indicate wrong settings of a certain linguistics in the words of the target language.

\section{The source of errors}

Generally, foreign language or second language learners' errors might be attributed to different sources or linguistic factors that might affect the pro- 
cess of English language learning such as L1 influence or the effect of target language itself. These linguistic factors are called interlingual and intralingual interference. They are considered as the two major linguistic factors that might negatively affect FL or L2 acquisition (Brown, 2000; Abisamra, 2003).

$\mathrm{Na}$ Phuket and Othman (2015) interlingual errors are caused by the interference of the native language. These errors are caused by the application of their native language in the written or spoken target language. It commonly happens that people tend to consciously or unconsciously draw connections between what they already know and what they have not been familiar with. Learners carry over knowledge from their native language to perform their target language.

Interlingual errors are caused by interference from the learner's L1, there are still some errors whose origins cannot be found in the structures of the learner's L1. In simple words, L1 does not play a role in producing such type of L2 learners' errors. Altamimi (2006) confirms what has been mentioned by Brown and asserts that the errors that do not reflect the structure of their NL or MT are caused by intralingual interference from the TL itself. He considers this type of interference as one of the major factors that might affect the process of SLA. They are independent of the learners' L1 (Jiang, 2009). Therefore, the errors, which are caused by the effect of the TL itself, are called intralingual errors. This indicates that interference from the learners' L1 is not the only cause for committing errors. More specifically, intralingual errors can occur as a result of negative interference or transfer from applying different general learning strategies similar to those noticeable in L1 acquisition.

\section{METHODS}

This research is qualitativedescriptive research. The purpose of the research is to find out the reasons why the students are unable to reach to the desired goal in acquiring L2. This paper seeks to investigate the learners' language output by analyzing the type and the source of the errors made by the science students of KIST College, Bhubaneswar, India.

The subjects chosen for the present research are the first year students. This research consisted of 200 students in the department of Science of KIST College, Bhubaneswar, India. They came from different mother tongues namely, Hindi, Odiya, and Bengal. English is the language instruction in the classes.

Multilingualism questionnaire is employed to probe into the experiential background of the students. This questionnaire contains six parts; information about family language background, students' language background, language use (code-switching), writing ability in the first language, and summary and comments. This questionnaire allows openended question types. Both of these measurements are complementary in terms of obtaining balanced information about native and second language acquisition.

A test of writing 500 words with a selected topic was also given for the analysis and experimentation. Types of errors on syntax in the learners' writing were identified and grouped. The sources of errors are classified into two domains; they are interlingual and intralingual errors.

This error analysis research applies some procedures, they are; collecting some data regarding the students' language experience, mother tongues, and language learning experience and this is very crucial as these data will be used to identify the errors. The next step is errors description which enables the researcher to consider and to describe the type of the errors made by the students. 


\section{FINDINGS AND DISCUSSION Findings}

The finding of this research indicates that interlingual errors are caused by several factors, some of them are the interferences of the na- tive language and intralingual errors within the target language. The present research identifies errors on the basis of Intralingual and Interlingual Errors as can be seen in the following table.

Table 1. Number and percent distribution of causes of errors

\begin{tabular}{ccc}
\hline Causes of Errors & Number & Percentage \\
\hline Interlingual Errors & 120 & $60 \%$ \\
Intralingual Errors & 70 & $39 \%$ \\
\hline
\end{tabular}

\section{Interlingual errors}

Linguistic interference of Indian students' mother tongue in their English writing are unavoidable features as the result of language contact. The occurance of this errors may happen automatically or sometimes it is intentionally done by the students because of the inadequate mastery of the language structure being learned particularly in the case of early stages before getting familiar with the system of the second language, the first language is the only previous linguistic system that the students have comprehended. The linguistic interference of the Indian language in
English, used in Indian contexts and situations, carry out communication purposes similar to those presented by any Indian language. Although somehow it deviates from the standard variation but it is the best medium for describing Indian thoughts and things in a very Indian way. In the absence of linguistic disorders from Indian languages, some Indian descriptions given in English will be stereotypical and mechanical. The results of this research reveal some crucial findings regarding the syntactical errors committed by the students. A clear elaboration can be seen from the table below.

Table 2. Number and percent distribution of the sources of interlingual errors

\begin{tabular}{lcc}
\hline \multicolumn{1}{c}{ Error Categories } & Number & Percentage \\
\hline Misordering & 95 & $48 \%$ \\
Misformation & 48 & $24 \%$ \\
Addition & 40 & $20 \%$ \\
Omission & 17 & $8,2 \%$ \\
\hline
\end{tabular}

Misordering is the highest error rate committed by the students with total percentage of $48 \%$. It is followed by other findings which reveal that $24 \%$ stu- dents committed misformation, 8,2\% students committed omission, and $20 \%$ students committed addition. 
Table 3. The details of inter lingual errors samples committed by the students

\begin{tabular}{|c|c|c|c|}
\hline No. & Errors & Reconstruction & Explanation \\
\hline 1. & $\begin{array}{l}\text { Learning my self study } \\
\text { is very good. }\end{array}$ & $\begin{array}{l}\text { I will be very good when I } \\
\text { learn alone. }\end{array}$ & $\begin{array}{l}\text { The word order in Hindi, Oriya, and } \\
\text { Bengal is: S-A/O-V. This may lead to } \\
\text { English misordering. }\end{array}$ \\
\hline 2. & $\begin{array}{l}\text { Learning with friends } \\
\text { any-any problem are } \\
\text { created. }\end{array}$ & $\begin{array}{l}\text { Learning with friends creates } \\
\text { more problems. }\end{array}$ & $\begin{array}{l}\text { In Bengali, Plural marker is used either } \\
\text { before the noun as a pre- determiner or } \\
\text { after the noun as plural inflection. But } \\
\text { not both at the same time so instead of } \\
\text { saying some problems, the student tend } \\
\text { to say any any problem. It indicates a } \\
\text { misformation. }\end{array}$ \\
\hline 3. & $\begin{array}{l}\text { When I study with } \\
\text { classmates, friends } \\
\text { support me. }\end{array}$ & $\begin{array}{l}\text { When I study with my class- } \\
\text { mates, they will support me. }\end{array}$ & $\begin{array}{l}\text { Pronoun Hindi exhibits a great deal of } \\
\text { ambiguity. Pronoun in the first, second, } \\
\text { and third person do not convey any in- } \\
\text { formation about gender. The confusion } \\
\text { of identifying pronoun may become the } \\
\text { cause. }\end{array}$ \\
\hline 4. & $\begin{array}{l}\text { With classmates study- } \\
\text { ing are more im- } \\
\text { portant. }\end{array}$ & $\begin{array}{l}\text { Studying with classmates is } \\
\text { more important }\end{array}$ & $\begin{array}{l}\text { The word order in Hindi, Oriya, and } \\
\text { Bengal is: S-A/O-V. This may lead to } \\
\text { English misordering. }\end{array}$ \\
\hline
\end{tabular}

Misordering is indicated by the incorrect placement of certain morphemes. Example: Learning my self-study is very good (correction: I will be very good when I learn alone). The main difference of Indian languages in this regards Hindi, Bengali, and Oriya compared to English lies in their word order. English is a SVO (Subject + Verb + Object) whereas Hindi, Bengali, and Oriya is a SOV (Subject + Object + Verb) language. This basic difference in word order often creates errors of wrong placement of verbs and adverbs in a sentence. In English adverbs may be placed either before or after the main verb depending on the meaning and context for example, he walks slowly and he always walks slowly. In Bengali, adverbs always come before the verb and if there is any adjective or noun (as object) preceding the verb, the adverb will appear in between the subject and object.

Addition is indicated by the presence of an 'unwanted' item in sentences. The unwanted items do not appear in a well-formed utterance. This happens when the learners overuse certain grammatical rules of the target language. Example: Learning with friends any-any problem are created (correction: Learning with friends creates more problem). In Bengali, Plural marker is used either before the noun as a pre- determiner or after the noun as plural inflection. But not both at the same time so instead of saying some problems, the students tend to say any any problem. This confusion is caused by the pronoun in Hindi which exhibits a great deal of ambiguity. Pronoun in the first, second and third person does not convey any information about gender. It can be seen from sample number 3 in which the students failed to write a correct pronoun of the word friends.

\section{Intralingual errors}

Errors in this category occur when the students are unable to handle the language properly. It is indicated that the main cause of intralingual errors is due to the students' limitation to be exposed to the target language. The intralingual errors 
include confusion between apparently similar words, inability to recall the correct word, wrong lexical choice and inappropriate word formation.

(1) Error: I am learning more always alone.

Reconstruction: I always learn more when I am alone.

Intralingual errors refer to items produced by learner due to generalization based on partial exposures of the target language. The research finding shows most of the students expose errors in tenses which indicate the lack of knowledge of tenses. It can be seen clearly from example number 1 , in which the students should write the sentence in the form of the simple present instead of present continuous. This is in line with the fact that English and Hindi share the same verb tenses, i.e. simple present, past, future, and so on. In Hindi, however, there is a deficiency in associating them to properly convey different meanings. Thus, Hindi speakers often find themselves using present continuous instead of the simple present (Vikram, 2013).

(2) Error: Whether you have time or not, must complete your project.

Reconstruction: Whether or not you have time, you must complete your project.

Some students omitted the use of pronouns altogether. The above sentence provides a sample of errors made by the students in the regard.

\section{Discussion}

The present research finds two sources of syntactical errors produced by the engineering students in India, they are interlingual errors ann intralingual errors. The analysis indicates that even though English has been used as a second language in India, Interference from the mother tongue is clearly a major source of difficulty in second language learning, and contrastive analysis has proven valuable in locating areas of the interlanguage errors. This is in line with some studies in different L1 context regarding the interference of L1 towards the students English. Some of the studies are; Kaweera (2013) deduced that there are two main sources of errors, namely interlingual and intralingual interference. The first one is a negative transfer of learners' first language. The other one involves errors caused by learners' incomplete knowledge of the target language. Tüm (2012) confirmed that interference from the mother tongue as an incomplete knowledge of L2 and the complexity of the L2.

Interlingual errors are found to be the most crucial factor affecting problems which result from negative transfer from mother tongue is clearly proven in this research finding hence, the second or foreign language learners of English will face a lot of obstacles. They are probably able to produce sentences which may be grammatically correct but will not sound English because of the interference of mother tongue. Walters (as cited in Dwivedi and Chakravarty, 2015) argues that students' writing may be grammatically correct, but unacceptable because of interference from the native language in style, usage, or arrangement of ideas." This research reveals that the students have committed four types of errors which mainly caused by the interference of L1. Alamin and Ahmed(2012) reveals different finding which indicates that the failure of students to understand basic English grammar can be ascribed to errors which are related to the sequence of development of learning English for technical communication in the form of speaking, listening, reading and writing than mother tongue interference.

This research indicates that the lack of trained English lecturers and the strategies employed in learning English 
become the main causes of intralingual errors produced by the students in India. Raja and Selvi(as cited in Raju and Josith, 2017) argue that most teachers do not know how to introduce new languages to students. This Confusion leads to the failures of teachers in making their students understand about second language features in this regards English. It is worsen by the fact that teachers from different background subjects are designated to teach English in class. In Indian tertiary level of education particularly in the rural areas, teachers who teach English do not always come from English as background subjects. This always creates problems among students. Students, who study in rural areas, perceive, 'attitude' and 'teacher competency' as causes of ESL learning problems than students in the city. In addition, Roy (2017) indicates that teaching English should be a continuous process. Unluckily, teachers in rural India are often hidered from attending workshops and seminars to acquaint themselves with new ways and methods. The ratio of students to teachers is high. This issue leads to ineffectiveness of teaching and learning process. The rural atmosphere, in which this reseach was taken place, does not provide students the opportunity to practice English particularly writing. Deshpande (2014) stated that a lack of exposure to the language in their day-to-day life outside the classroom proves to be a barrier to their acquisition of the English communication skills in India context added to that the students have a low encouragement to read and write.

\section{CONCLUSIONS}

It can be concluded that the sources of Syntactical errors committed by the students in India context are mainly influenced by both interlingual and intralingual. The Inter-lingual errors are dominated by word orders particularly on the sentence constructions. In English, subject-verb-object or adverb, but in Hindi, Oriya, and Bengali, the sentence constructions follow this rule: subject-object or adverb-verb. This different structure leads to the interference of the students' mother tongue in English writing errors production. The intra-lingual errors are mainly caused by the lack of trained English lecturers and the strategies employed in learning English particularly writing.

It can be implied that the current English course for the students of engineering particularly writing needs to be reviewed in term of choosing the right teaching materials. Teachers should make an analysis of the students' shortcomings and they should concentrate on particular syntactical errors which occur repeatedly, so that the syntactical errors can be rectified. The overcrowded of college classes may become another factor that leads to unsuccessful learning if the strength of the classes is reduced to a reasonable level, the students' performance may be increased. The course contents are required to be more activity-based learning than to be more theoretical.

It is very important that the students are exposed with the English for Specific Purpose (ESP) material which is most appropriate with the teaching syllabus for the Engineering students integrated with grammar practices. There must be an adequate number of repetitions and reviews. Cognitive strategies should be applied to involve practice and repetition as well as the creation of grammatical structures for input and output. It can improve students' knowledge about the grammar and structure of English. Students need to be monitored on their grammar. This also means to increase the awareness of students about intralingual differences related to syntax. They need to be encouraged to use both dictionaries and out of the classroom. 


\section{REFERENCES}

Alamin, A., \& Ahmed, S. (2012). Syntactical and Punctuation Errors: An Analysis of Technical Writing of University Students Science College, Taif University, KSA. English Language Teaching, 5(5). doi:10.5539/elt.v5n5p2.

Al-Khresheh, M. H. (2016). A review study of contrastive analysis theory. Journal of Advances in Humanities and Social Sciences, 2(6). doi:10.20474/jahss-2.6.5.

Al-Tamimi, A. (2006). An investigation of interlingual and intralingual interference in the acquisition of English present tenses by Yemeni learners (Unpublished master's thesis). Universiti Sains Malaysia, Penang, Malaysia.

AbiSamra, N. (2003). An Analysis of Errors in Arabic Speakers' English Writings (Master's thesis, American University of Beirut). Retrieved from http://abisamra03.tripod.com/nada/ languageacq-erroranalysis.html.

Abusaeedi, R., \& Asghar, A. (2015). A Quantitative Analysis of Iranian EFL Learners' Sources of Written Errors. International Journal of Research Studies in Language Learning, 4(1), 31-42. doi:10.5861/ijrsll.2014.682.

Amin, A. A. (2017). Linguistic Analysis of the Phenomenon of Language Transfer. IOSR Journal of Humanities and Social Science, 22(04), 32-35. doi:10.9790/08372204043235.

Brown, H. D. (n.d.). Principles of language learning and teaching (4th ed.). San Francisco : Pearson Education Limited.

Cumming, A. (2003). Learning to write in a second language: Two decades of research. International Journal of English Studies, 2, 1-23.
Retrieved from https://tspace.library.utoronto.ca/bi tstream/1807/32148/1/Learning\%2 0to\%20Write\%20in\%20a\%20Seco nd $\% 20$ Language-

Two\%20Decades\%20of\%20Resea rch.pdf

Deshpande, S. (2014). Teaching Writing Skills In English: Involvement Of Students In The Assessment And Correction Of Their Own Errors. International Journal of English Language Teaching, 3(1), 68-73. Retrieved from http://www.eajournals.org/wpcontent/uploads/Teaching-WritingSkills-in-English-Involvement-ofStudents-in-the-Assessment-andCorrection-of-Their-OwnErrors.pdf.

Dwivedi, R. S., \& Maharaj, S. (2015). Problems Encountered By Rural Students in Writing English - Role of English Teacher - Some Solutions. International Journal on Studies in English Language and Literature, 3(7), 27-38. Retrieved from https://www.arcjournals.org/pdfs/ij sell/v3-i7/4.pdf.

Gass, S., \& Selinker, L. (2008). Second language acquisition : An Introductory Course. New York, NY: Routledge.

Gayo, H., \& Widodo, P. (2008). An Analysis of Morphological and Syntactical Errors on the English Writing of Junior High School Indonesian Students. International Journal of Learning, Teaching and Educational Research, 17(4), 5870. doi:10.1108/03090560710821161.

Hadley, A. O. (2001). Teaching language in context (3rd ed.). Boston: Heinle \& Heinle.

Hyland, K. (2003). Second language writing. Cambridge University Press, 1(1), 1-5. Retrieved from 
doi.org/10.1017/CBO9780511667 251

Ismaili, M. (2015). Teaching English in a Multilingual Setting. Procedia Social and Behavioral Sciences, 199, 189-195. doi:10.1016/j.sbspro.2015.07.505

Jayasundara, J. M., \& Premarathna, C. D. (2011). ) A Linguistic Analysis of Errors Committed in English by Undergraduates. International Journal of Scientific Research and Publication, 1(1), 1-6. Retrieved from

http://www.ijsrp.org/research_pap er_dec2011/ijsrp-dec-2011-05.pdf

Jiang, W. (2009). Acquisition of Word Order in Chinese as a Foreign Language. Studies on Language Acquisition.

doi:10.1515/9783110216196

Kaweera, C. (2013). Writing Error: A Review of Interlingual and Intralingual Interference in EFL Context. English Language Teaching, 6(7). doi:10.5539/elt.v6n7p9

Leki, L. (2001). Material, Educational, an Ideological Challenges of Teaching EFL Writing at the Turn of the Century. International Journal of English Studies, 1, 197209.. Retrieved from https://digitum.um.es/jspui/bitstrea $\mathrm{m} / 10201 / 2108 / 1 / 211098$.pdf

Littlewoods, W. (2002). Foreign and Second Language Learning. Cambridge: Cambridge University Press.

Ngangbam, H. (2016). Org An Analysis Of Syntactic Errors Committed By Students Of English Language Class In The Written Composition Of Mutah University: A Case Study. European Journal of English Language, Linguistics and Literature, 3(1), 1-15. Retrieved from www.idpublications.org/wpcontent/uploads/2016/01/Full-
Paper-AN-ANALYSIS-OF-

SYNTACTIC-ERRORS-

COMMITTED-BY-STUDENTS-

OF-ENGLISH-LANGUAGE.pdf.

Ondrakova, J. (2016). The Issue of Errors in Teaching Foreign Languages. Procedia - Social and Behavioral Sciences, (217), 101-108. Retrieved from https://ac.elscdn.com/S1877042816000628/1s2.0-S1877042816000628main.pdf?_tid=3a9a5b26-4e6b46cd-a579af74914c8128\&acdnat $=15495120$ 65_f883e297c27059a5a649384d96 $9 \mathrm{e} 3 \mathrm{cda}$

Owu-Ewie, C., \& Lomotey, C. F. (2016). L1 Interference Errors in L2 (English) Writing:The Case of Three Junior High School Students in Ghana. American Journal of Language and Literacy, 1(1), A1A10. Retrieved from http://www.ASRAresearch.org/ajll -vol-1-no-1-2016/

Raju, N., \& Joshith, V. P. (2017). Adversities and obstacles in learning English as a second language in Indian context. International Journal of Advanced Education and Research , 2(4), 4851. Retrieved from file://C:/Users/hp/Downloads/2-418-719\%20(2).pdf

Rattanadilok, N. P., \& Normah, B. U. (2015). Understanding EFL Students' Errors in Writing. Journal of Education and Practice, 6(32), 2222-1735. Retrieved from https://files.eric.ed.gov/fulltext/EJ 1083531.pdf

Ratti, L. (2015). The Three Language Formula:Challenges in Its Implementation in Multilingual India. International Journal of English Language Literature and Translation Studies (IJELR), 2(2), 
245-258. Retrieved from http://www.ijelr.in/2.2.15.html

Roy, N. (2014). Challenges in Indian

Classrooms to teach English as a Second Language. In Conference proceedings, ICT for language learning. 10th Edition. (pp. 1-3). Retrieved from https://conference.pixelonline.net/ICT4LL/files/ict411/ed0 010/FP/3978-SLA2572-FP-

ICT4LL10.pdf

Tizazu, Y. (2014). A Linguistic Analysis of Errors in Learners' Composition:The Case of Arba Minch University Students. International Journal of English Language and Linguistics, 2(2), 69-101. Retrieved from https://www.eajournals.org/journal s/international-journal-of-englishlanguage-teaching-ijelt/vol-2- issue-1-march-2014/linguisticanalysis-errors-learnerscompositions-case-arba-minchuniversity-students/

Vikram, S. (2013). Morphology:Indian Languages and European Languages. International Journal of Scientific and Research Publications, 3(6), 1-5. Retrieved from http://www.ijsrp.org/researchpaper-0613/ijsrp-p18124.pdf.

Watcharapunyawong, S., \& Siriluck, U. (2013). Thai EFL Students' Writing Errors in Different Text Types: The Interference of the First Language. Journal of English Language Teaching, 6(1), 67-78. Retrieved from https://files.eric.ed.gov/fulltext/EJ 1076889.pdf. 